Bulletin UASVM Food Science and Technology 70(2)/2013, 114-117

ISSN-L 2344-2344; Print ISSN 2344-2344; Electronic ISSN 2344-5300

\title{
Quality Control of Wild Berries Honey Syrup
}

\section{Laura STAN, Alina Maria HÎNGAN, Sevastiţa MUSTE*}

\author{
Faculty of Food Science and Technology, University of Agricultural Sciences and Veterinary \\ Medicine Cluj-Napoca; 3-5 Calea Mănăştur, 400372 Cluj-Napoca, România; \\ sevastita.muste@usamvcluj.ro
}

\begin{abstract}
This paper presents the quality control parameters of wild berries honey syrup . The product was created in laboratory (wild berries: honey, 1:4 w/w) and there were no changes recorded in overall quality over 6 months preservation at $1-2^{\circ} \mathrm{C}$. Basic quality parameters of the product were evaluated: humidity, $\mathrm{pH}$, acidity, hydroxymethylfurfural, diastase, total sugars and ascorbic acid. Methods developed by Internantional Honey Commission and Romanian Food Quality Standards were applied during this study. The product presented qood quality criteria and it was highly appreciated by consumers who tasted it. This study presents a valuable method to preserve fresh widberries in honey over a long period of time. The economical value of this experiment resides in making these fruits available outside the harvesting season.
\end{abstract}

Keywords: wild berries syrup, quality control

\section{INTRODUCTION}

Wild berries are known for their rich content in natural active principles like polyphenols, vitamins and pigments beneficial to human health: enhance immunity by increasing Bifidobacteria in human gut (Vendrame, 2011), reduce cholesterol (Kalt, 2008) and inhibit DNA damage, improves vascular tone (Kristo, 2010). Ideally, berries are consumed fresh. Two factors reduce drastically the consumption period in fresh state to 1-2 months from the whole year: 1) composition liable to rapid alteration and 2) seasonal production and harvesting time frame is very short. One way to extend the shelf life of berries three-fold (up to 5-15 days) is by ionising irradiation (Enăchescu Daughty, 1995). Due ot their high nutritional value and increasing interest of consumers for healthy foods there is a real market need to have available these berries in fresh state for a longer period of time.

Honey is well known in traditional cuisine as a good preserver of fruits. Egyptians and Chinese used to preserve fruits in large honey jars placed in caves with low temperatures. Honey has great qualities as natural preserver due to low $a_{w}$ and high acidity (Mărghitaş, 2005).

This study is focused on developing a product made from wild berries and multifloral honey and its quality control after preservation for 6 months at $1-2^{\circ} \mathrm{C}$.

\section{MATERIALS AND METHODS}

The research has been carried out in Laboratory for Food Quality Control and Safety in USAMV Cluj-Napoca. The fresh wild berries (cranberries and raspberries) used in this study were collected in 2012 from Harghita area, Bihor county, Romania. Multifloral honey from the same region was collected in autumn 2012. The product (wildberries honey syrup) was prepared 
using 1:4 ratio (w/w) fresh wild barriers/honey and was stored at $1-2^{\circ} \mathrm{C}$ until analysis (see Tab. 1 for identification of sample code). All chemicals (p.a. purity) were purchased from Chemomed (Romania) and all determinations were performed in duplicate. Apparatus used in this study are: digital refractometer Abbe; pH-meter Schott Duran, spectrophotometer UV-VIS 1700 Schimadzu, Japan.

Tab. 1

Samples used in the study

\begin{tabular}{|l|c|c|}
\hline \multicolumn{1}{|c|}{ Sample } & Code & Preparation \\
\hline Multifloral honey & MH & $100 \%$ multifloral honey \\
\hline Cranberries & C & $100 \%$ Cranberries \\
\hline Raspberries & R & $100 \%$ Raspberries \\
\hline Cranberries honey syrup & CHS & Cranberries: multifloral honey 1:4 (w/w) \\
\hline Raspberries honey syrup & RHS & Raspberries: multifloral honey 1:4 (w/w) \\
\hline
\end{tabular}

Quality control was evaluated as follows:

1) fruits: humidity, dry matter, inverted sugar, ascorbic acid;

2) honey: humidity, $\mathrm{pH}$, free acidity, diastase and hydroxymethylfurfural;

3) wild berries honey syrup: humidity, $\mathrm{pH}$, free acidity.

Methods developed by International Honey Commission for quality control of honey were applied in this study for evaluation of the following quality parameters: humidity, $\mathrm{pH}$, free acidity and hydroxymethylfurfural. Diastase was determined by Gothe method (STAS 784/89). Inverted sugars from berries were determined using Schoorl method (Muste, 2011). Ascorbic acid from berries was determined by titration with 2-6 dichlorophenylindophenol (Muste, 2011).

\section{RESULTS AND DISCUSSIONS}

The product obtained syrup of wildberries and honey had an appealing taste and color, which was highly appreciated by consumers who tasted the product. Physico-chemical analyses of the wildberries are presented in Tab. 2. The fruits presented good quality parameters, according to standard reglementations.

Tab. 2

Quality parameters of fresh wildberries used in the study

\begin{tabular}{|c|c|c|c|c|}
\hline $\begin{array}{c}\text { Sample } \\
\text { code }\end{array}$ & $\begin{array}{c}\text { Humidity } \\
(\%)\end{array}$ & $\begin{array}{c}\text { Dry matter } \\
(\%)\end{array}$ & $\begin{array}{c}\text { Inverted sugar } \\
(\%)\end{array}$ & $\begin{array}{c}\text { Ascorbic acid } \\
(\mathrm{mg} \%)\end{array}$ \\
\hline $\mathrm{C}$ & $81,32 \pm 3,03$ & $18,67 \pm 1,6$ & $29 \pm 2,34$ & $12,85 \pm 1,09$ \\
\hline $\mathrm{R}$ & $77,08 \pm 2,98$ & $22,91 \pm 1,4$ & $23,2 \pm 2,16$ & $24,78 \pm 2,46$ \\
\hline
\end{tabular}

Literature data from FAO about quality parameters of berries mention 70-97\% humidity (Bates, 2001) and rich in flavonoids, vitamins and minerals, carbohydrates 8,3\% (Enăchescu Daughty, 1995). Berries are also known for high acidity (Pihlström, 2009). 
It can be noticed that the honey $(\mathrm{MH})$ used presented a very good quality according to the limits of European reglementations (EC 110/2001). Maximum humidity admitted is 20\% while MH sample presented $15,6 \%$. The free acidity should be below 50 mili-equivalents $/ \mathrm{kg}$ while the analysed sample $\mathrm{MH}$ had $14,67 \mathrm{mEq} / \mathrm{kg}$. Very low amounts of HMF $(9,345 \pm 0,88$ $\mathrm{mg} / \mathrm{kg}$ ) indicate that the honey sample was not submitted to heating. The maximum admitted by EC $110 / 2001$ is $40 \mathrm{mg} / \mathrm{kg}$. Diastase determined in MH was 10,86 Goethe units while STAS 784/89 implies minim 6,5. Honey sample $\mathrm{MH}$ was a typical multifloral honey with good quality parameters.

Tab. 3

Quality parameters of multifloral honey and wildberries syrups prepared for this study

\begin{tabular}{|c|c|c|c|}
\hline $\begin{array}{c}\text { Sample } \\
\text { code }\end{array}$ & $\begin{array}{c}\text { Humidity } \\
(\%)\end{array}$ & $\mathrm{pH}$ & $\begin{array}{c}\text { Free acidity } \\
(\mathrm{mEq} / \mathrm{kg})\end{array}$ \\
\hline MH & $15,6 \pm 0,74$ & $4,23 \pm 0,02$ & $14,67 \pm 0,58$ \\
\hline CHS & $50,3 \pm 1,4$ & $3,68 \pm 0,03$ & $100,00 \pm 2,00$ \\
\hline RHS & $41,4 \pm 1,2$ & $3,97 \pm 0,02$ & $90,67 \pm 1,53$ \\
\hline
\end{tabular}

The combination between the wildberries with high amount of water (Tab. 2) and honey with low humidity lead to wildberry syrups with high humidity wich would not resist storage for long time at room temperature (Tab. 3). Adding wildberries to honey modify drastically the values of CHS and RHS free acidity increasing it about 9 times (Tab. 2) compared to MH.

Traditional ways to preserve wild berries used so far include chemical preservation, freezing or shelf pasteurization (Enăchescu Daughty, 1995). Codex Alimentarius prepared since 2003 a document regarding hygienic conditions for berries handling (CAC/RCP 53-2003).

\section{CONCLUSION}

The traditional means to preserve wild berries is by chemical preservation, freezing or shelf pasteurization. In this article authors proved that preservation of fresh wildberries in honey is possible due to specific characteristics of honey. This product is useful for stimulating and maintaining immunity due to high capacity of honey to preserve the vitamins and polyphenols of wildberries. Due to high increase of humidity which may lead to honey fermentation this product must be kept at low temperature $\left(1-2^{\circ} \mathrm{C}\right)$ in case it is intended to use in other seasons when fresh wildberries are not available. Further studies about the dynamism of vitamins and polyphenols in the honey syrup may bring new data about the bioavailability of the product.

\section{REFERENCES}

1. Bates, R.P., Morris, J.R., Crandall, P.G., 2001, Principles and practices of small-and mediumscale fruit juice processing, FAO Agricultural Services Bulletin 146

2. Codex Alimentarius, Proposed Draft Annex on Berries to the Code of Hygienic Practice for Fresh Fruits and Vegetables, CAC/RCP 53-2003, 86-118

3. Enăchescu Daughty, M., 1995, Fruit and vegetable processing, FAO Agricultural Services Bulletin 119

4. Kalt, W., Foote, K., Fillmore, S. A. E., Lyon,M., Van Lunen, T. A., McRae1, K. B., 2008, Effect of blueberry feeding on plasma lipids in pigs, British Journal of Nutrition, 100, 70-78, doi:10.1017/S0007114507877658. 
5. Kristo, A.S., Kalea, A.Z., Schuschke, D.A., Klimis-Zacas D.J., 2010, A wild blueberry-enriched diet (Vaccinium angustifolium) improves vascular tone in the adult spontaneously hypertensive rat, $\mathbf{J}$ Agric Food Chem., Nov 24;58(22):11600-5.

6. Mărghitaș, L.A., Albinele și produsele lor, 2005, Editura Ceres

7. Muste, S., Mureșan, C., 2011, Controlul calității materiilor prime de origine vegetală - Caiet de lucrări practice, Editura AcademicPres, Cluj Napoca, 45-46

8. Official Journal of the European Communities:Council Directive 2001/110/EC of 20 December 2001 realting to honey; L10/47-L10/52

9. Pihlström, T., 2009, Method Validation and Quality Control Procedures for Pesticide Residues Analysis in Food and Feed, Document No. Sanco/10684/2009

10. STAS 784/1-3/89, Miere de Albine - Metode de Analiză.

11. Swiss Bee Research Centre, 2002, Harmonised methods of the International Honey Commission Vendrame, S., Guglielmetti, S., Riso, P., Arioli, S., Klimis-Zacas, D., Porrini M., 2011, Six-week consumption of a wild blueberry powder drink increases bifidobacteria in the human gut, J Agric Food Chem. 28; 59(24):12815-20. doi: 10.1021/jf2028686. 